\title{
Canada As A Country Of First Asylum
}

\author{
by David Matas
}

Should Canada be a country of first asylum for refugees that choose to come to Canada? Or should we be a country of secondary resettlement, and first asylum only for those refugees the Government of Canada chooses to admit?

Right now only a few refugees choose Canada as a country of first asylum. The overwhelming majority of refugees Canada accepts each year are chosen by Canada either from their country of origin or from countries of first asylum.

The Government of Canada has put obstacles in the way of refugees who wish to choose Canada as a country of first asylum. The pattern has been that whenever there has been a significant inflow of refugees from a particular country into Canada, Canada has imposed a visa requirement on that country. In recent years, Canada has imposed visa requirements on Chile, Haiti, India, Sri Lanka, Guatemala, Peru and Guyana, to stop people of those countries from coming to Canada to claim refugee status here.

The visa requirement is a requirement that a person must have a visitor's visa issued at a Canadian post abroad before he appears at a Canadian port of entry for entry as a visitor. Practically, what is more important is that airlines will not transport to Canada a person national of a country with a visa requirement and who does not have a visa. The Immigration Act imposes on airlines the costs of detention and removal of persons brought to Canada without visas who should have them.

\section{The Government of Canada}

Officials of the Government of Canada have justified this refusal to allow Canada to become a country of first asylum for those refugees who choose to come here. They argue that Canada is not geographically proximate to any refu- gee producing country. The appropriate countries of first asylum are those countries geographically proximate to refugee producing countries. For instance, the appropriate country of first asylum for Sri Lankan refugees would be India, not Canada.

Geographically proximate countries are culturally similar. Adaptation of the refugee is easier. The ideal solution to any refugee problem is removal of the situation that caused the refugee outflow, and repatriation. Repatriation is more effectively done from a geographically proximate country than from a geographically remote country like Canada.

For those who cannot flee to a neighbouring country, and for whom Canada is a logical and accessible choice of first asylum, the Government of Canada has established the political prisoners and oppressed persons designated class. Citizens of countries within that class can apply from within their own countries to come directly to Canada. Countries currently within that class are Guatemala, El Salvador, Argentina, Chile, Uruguay and Poland.

Imposing a visa requirement does not mean stopping refugee access to Canada. In fact, by international standards, Canada is one of the more generous countries for refugee resettlement. Canada accepts more than its share of the international burden of refugee resettlement. All a visa imposition does is regulate the flow. Instead of refugees choosing Canada, it is the Government of Canada that chooses the refugees.

If the Government of Canada chooses a refugee abroad, once the person enters Canada, he enters as a permanent resident, or as a person the Government has decided can become a permanent resident. He is free to work or go to school. He has access to the services and benefits available to Canadians.
If a person comes here on his own as refugee claimant, he will be here for months, in many cases, even years while his claim is being processed. Dur ing that time he is in a state of limbo. $\mathrm{He}$ is treated as a temporary resident until his status is determined. He is sev erely restricted in his access to work, to school, to medicare, to all government services and benefits.

The Government of Canada admit refugees to meet a need, not to cater to preference. By selecting refugees? abroad, the Government of Canada can make a determination of need Without selection, those refugees who arrive may well be refugees who could have received protection elsewhere but who just preferred Canada as country of immigration.

If the Government of Canada were to allow refugees the choice of coming to Canada as a country of first asylum then, instead of directing Canada's refugee resources to resettling our fair share of the world's refugees, we would have to direct our refugee resources to. those who chose Canada. We would be able to resettle fewer of those we deter? mine to be in need. Instead, we would be offering asylum, in preference, those refugees who might be protecte elsewhere.

Allowing refugees to choose to come to Canada as a country of first asylum means allowing entry not only to gen uine refugees. It means allowing entry as well, to those who are not refugees but who wish to gain entry to Canada. even if only temporarily, by abusing the refugee claims system. It is only cutting off access to the refugee claing system, by imposing visa requirements. that the Government of Canada can control this abuse. With a visa requirt ment, when the Government of Canads selects refugees abroad, it selects ger uine refugees and avoids the entry in Canada of frivolous refugee claimant 
Finally, a visa exemption allows oppressive regimes to expel their opponents. A foreign dictator may take advantage of a Canadian visa exemption to get rid of this opposition, forcing them into Canada. A visa exemption can be an aid to a foreign oppressor, rather than an aid to refugees.

\section{Non-Governmental Organizations}

That is the rationale that has been put forward for the imposition of a visa requirement to control Canadian refugee intake. It is not a rationale that has persuaded Canadian non-governmental organizations. In a meeting held recently in Toronto, sponsored by the Canadian Section of Amnesty International, a number of non-governmental organizations (NGO's) came together to discuss the question of Canada as a country of first asylum. All the NGO's represented, the Canadian Council of Churches, the Canadian Labour Congress, the Canadian Jewish Congress, the Canadian Bar Association, and Amnesty itself, took the position that Canada should be a country of first asylum for refugees who choose to come to Canada. Canada should not :mpose a visa requirement on a refugee producing country as a means of regulating the refugee inflow to Canada.

The attitude of the NGO's was that visa imposition was not appropriate as a form of abuse control. The way to control abuses is to speed up the refugee determination process in Canada. Now

I the system can take years to arrive at a final determination. The delays are an incentive to abuse. If the system is - speeded up, the incentive will be gone. A person will not incur the expense and dislocation of coming to Canada if he is to be expelled shortly after his arrival.

A visa imposition does not just keep out of Canada those who might abuse the Canadian refugee claims system. It keeps out genuine refugees as well. Denial of access to genuine refugees can be a denial of protection.

Canada, along with all other Signatories to the Refugee Convention, has a duty of non-refoulement, a duty not to return a refugee to a country where his life or safety would be threatened. A visa imposition is a form of violation of this obligation of non-refoulement. There is little difference, to the refugee, between being forced to return from Canada to his country, and not being allowed to come from his country to Canada in the first place.

If a visa exemption means that it is the refugee who chooses Canada, rather than Canada's choosing the refugee, that is the consequence of the Refugee Convention. Signatories are not free to choose whether or not to protect refugees. They are obliged to protect refugees. It is not the Signatories countries that make a person a refugee by choosing him. It is the person with a well founded fear of persecution who makes himself a refugee, by choosing to flee his country.

Practically speaking, a neighbouring country may not be an appropriate refuge. Refugee camps bordering the country of persecution are often viewed by the government of that country as terrorist camps. The camps may be bombed. They may be subjected to intensive cross border raids by the military of the country of persecution.

Often, neighbouring countries are ideologically similar to the country of persecution. On occasion, they actively participate in the persecution of the refugees within their borders. Whether they participate or not, refugees fear that they will assist the country of origin in persecution.

People in refugee camps can end up being there for long periods of time. Life in the camps is one of unmitigated misery, squalid poverty, hunger, disease, and enforced inactivity. If the international refugee burden sharing system were working effectively, and people were moving out of the camps quickly, then the camps might be a viable first step. Because of the prolonged delays refugees face in getting out of a camp once in, insisting all refugees go to camps is cruel.

There are real difficulties with the Canadian refugee selection system abroad. It is not true to say that the Government of Canada selects refugees only on the basis of refugee needs. The Government also considers Canada's needs. The Government chooses refu- gees that are likely to establish themselves successfully in Canada. It chooses the cream of the refugee crop. It picks a disproportionately small share of the illiterate, the handicapped. the old, the young, the unskilled.

A refugee lawfully in Canada has a right to remain. A refugee in Canada will be given lawful permission to stay if there is no other country that has already given him protection. A refugee outside of Canada has no right to enter, even if he has no protection from any other country. A refugee outside of Canada who needs a visa to get here has to satisfy the likelihood of successful establishment criterion. A refugee inside does not have to satisfy that criterion. He can stay no matter what his skills, his age, his education, his job offers.

It can be difficult for a person at a Canadian post abroad to establish that he is a refugee. The claimant abroad does have an oral hearing, something he does not have, as a right, in Canada. However, abroad, he is not entitled to the assistance of counsel to help him establish his claim. The government officers who make the decision are not necessarily refugee experts, knowledgeable in the refugee definition, and knowledgeable in the conditions of the country from which the refugee has fled. The officers who decide are not independent of the Immigration Commission and the Department of External Affairs. There is no appeal to the Canadian courts from a refusal to recognize someone as a refugee, even where that refusal is wrong in law.

If a person is allowed to enter Canada to make a refugee claim, he is entitled to the assistance of counsel in making his claim. The people who advise the Minister of Immigration on the claim, the members of the Refugee Status Advisory Committee, are experts in the refugee definition and on country conditions. The Committee is independent of the Immigration Commission and the Department of External Affairs. There is an appeal to the courts from a Ministerial refusal that is wrong in law.

When it comes to refugee claims directly from within the country of persecution, 


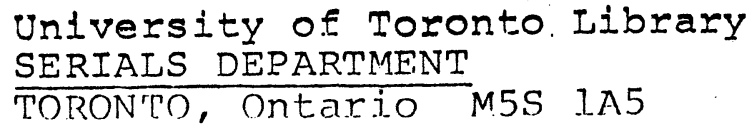

the problems with the Canadian claims system abroad are even more acute. A claimant in his own country may simply be denied access by the local military to the Canadian embassy. If he is allowed access, the Canadian embassy may, nonetheless, be under local military surveillance. A person may jeopardize his safety simply by approaching a Canadian embassy to make a claim. Even if there is access, even if there is no surveillance, a claimant may fear that there is surveillance, and refuse to approach the Canadian embassy because of that fear.

Once a claim is made at a Canadian post abroad, it is not processed immediately. Processing can take six months or more. During that time, the claimant remains in his country, in danger. A claimant may need refuge immediately, not six months.

Canadian posts abroad employ some domestic staff, nationals of the host country. A claimant making a claim in his own country may fear that the confidentiality of his claim will be jeopardized by the nationals of his country in Canadian employ. He will be reticent to put forward all the details of his claim in such a context.

When a refugee makes a claim in his own country, others may not be willing to assist him in putting forward his claim, because they feel they would jeopardize themselves if they assisted. For instance, doctors in Canada are quite willing to examine refugee claimants and to provide medical reports of the sequelae of torture, to show that claimants have been tortured. Doctors in the country of torture may be reluctant to provide such reports, for fear of putting themselves in danger.

There is the message that a visa imposition gives to an oppressive regime. It is as if the Government of Canada is saying that it washes its hands of the problem. it is not concerned with the violations that have caused the refugee problem.

A Canadian visa imposition can lead to a foreign visa imposition. Visa exemptions are often reciprocated. Mutual visa impositions make it more difficult for Canadians who want to go to the country of persecution to assist the persecuted. Canadian doctors or aid workers will need visas, and may be denied them.

\section{Conclusion}

The visa imposition that gave the NGO's the most concern was the visa imposition for Guatemala. Canada im posed a visa requirement for Guatemalt in March 1984. At that time, the refu gee inflow into Canada was small 244 claims were made in 1983. The abuse was minimal - the acceptanc rate for claims was $70.5 \%$. Canadk. coupled the visa imposition with the introduction of a system of processin. claims made from within Guatemale. When Canada imposed a visa require ment on Guatemala, Guatemala im posed a visa requirement on Canada.

The feeling of the NGO's was that the visa imposition for Guatemala was jus not appropriate. The general conclu sion of the symposium was that wher the numbers are manageable, wher the abuses are small, where the cout tries of origin are violating huma rights in a gross and flagrant manne. and where Canada is a logical an accessible country of refuge, ther should not be a visa requiremen Guatemala met all of these require ments.

David Matas is a lawyer in private practice in Winnipeg. He attended the NGO symposium on "Canada as $\boldsymbol{a}$. Country of First Asylum" for the Canadian Bar Association. 